\title{
BIOSTRATIGRAPHY OF THE MIOCENE SUCCESSIONS IN THE SADAT AREA, WEST GULF OF SUEZ-EGYPT
}

\author{
Hewaidy A. A., Ayyad, H. M., Ahmed, N. \\ Geology Department, Faculty of Science, Al-Azhar University, Nasr City, Cairo, Egypt
}

\begin{abstract}
The age of the exposed Sadat, Hommath and Hagul formations in Sadat area on the west side of the Gulf of Suez, is inadequately resolved due to the scarcity of diagnostic planktic foraminifera and calcareous nannofossil taxa. The detailed analysis of the calcareous nannofossil content, planktic and larger benthic foraminifera of three sections measured in Wadi El-Ramiya, Wadi Hommath and Wadi Hagul at Sadat area, allows identification of 23 calcareous nannofossil species, 23 planktic foraminiferal species and 152 benthic foraminiferal species. Our results indicate that the Sadat Formation is assigned to Burdigalian-Langhian age according to the occurrence of Miogypsina cushmani and Miogypsina intermedia in its lower part and the appearance of Borelis melo in its upper part. The Hommath Formation is assigned to the Langhian-Serravallian age depending on the occurrence of Borelis melo curdica together with Borelis melo melo. The Hagul Formation is barren from any zonal marker but it is assigned to the late Miocene age according to its stratigraphic position.
\end{abstract}

Keywords: Miocene biostratigraphy, microfossil content, larger benthic foraminifera, Sadat Area.

\section{INTRODUCTION}

The Sadat area lies in the west side of the Gulf of Suez about $30 \mathrm{~km}$ southwest of the Suez city. The Miocene sediments are widely distributed in the Sadat area, it is forming a low land bounded from the north and south by Eocene rocks (Fig. 1). The importance of the Sadat area comes from being a source of calcium carbonate that exploited in the fertilizers and chemical industries company Cherif (1966). Many workers have been studied the Miocene rocks of the Sadat area such as Sadek (1926 and1959), Metwalli (1964), Abdallah and Abdelhady (1968), Cherif (1966), Youssef et al (1971 and 1973), N.S.S.C (1974), Abbass (1977), Cherif and Yehia (1977), Abdelshafy and Abdelmoneim (1992), Elsorogy and Ziko (1999), Ismail and Abdelghany (1999), El-Azabi (2000), Strougo et al (2006), Hamad (2009) and Elattaar (2003 and 2017). The present work focused on the integration between calcareous nannofossils and foraminifera to refine and increase the resolution of the age of the Miocene succession in the Sadat area.

\section{LITHOSTRATIGRAPHY}

Three Miocene formations in the Sadat area of the northern part of the Gulf of Suez, at the foot slopes of Gebel Ataqa, were recognized by Abdallah and Abdelhady (1968). These are: Sadat, Hommath and Hagul formations. The aerial distribution of the studied formations is illustrated in a geologic map at scale of 1:100,000 (Fig.1) (modified after Conoco, 1987). The Sadat Formation which is named after a quarry carrying the same name crops out at the southern scarp of Gebel Ataqa and also cover the cliffs bordering the coastal plain from Barabir hills to the mouth of Wadi Hommath (Issawi et al., 1999). It consists of 52 $\mathrm{m}$ thick of limestone with marls and sandy marl intercalations. It unconformably overlies middle or upper Eocene units that are separated by a conglomerate bed (Abdallah and Abdelhady, 1968; Fig. 2). Lithologically, the Hommath Formation is a $54 \mathrm{~m}$ thick made of shales, marls, limestone, sandstone and grits. It unconformably overlies the Sadat Formation and unconformably underlies the Hagul Formation (Abdallah and Abdelhady, 1968; Fig. 2). The Hagul Formation overlies the Hommath Formation and is made of $19 \mathrm{~m}$ thick of chalky limestone, sandstone and shale (Fig. 2). The lithological characteristic of these formations and their faunal contents suggest a permanent connection between the northern part of the Gulf of Suez and the Mediterranean Sea since the Chattian (Issawi et al., 1999; Popov et al., 2004; Gargani et al., 2008., Ayyad et al., 2018). 
Hewaidy, et al.

Fig. 1; Geologic map of the study area, showing the location of the measured sections (modified after Conoco, 1987).

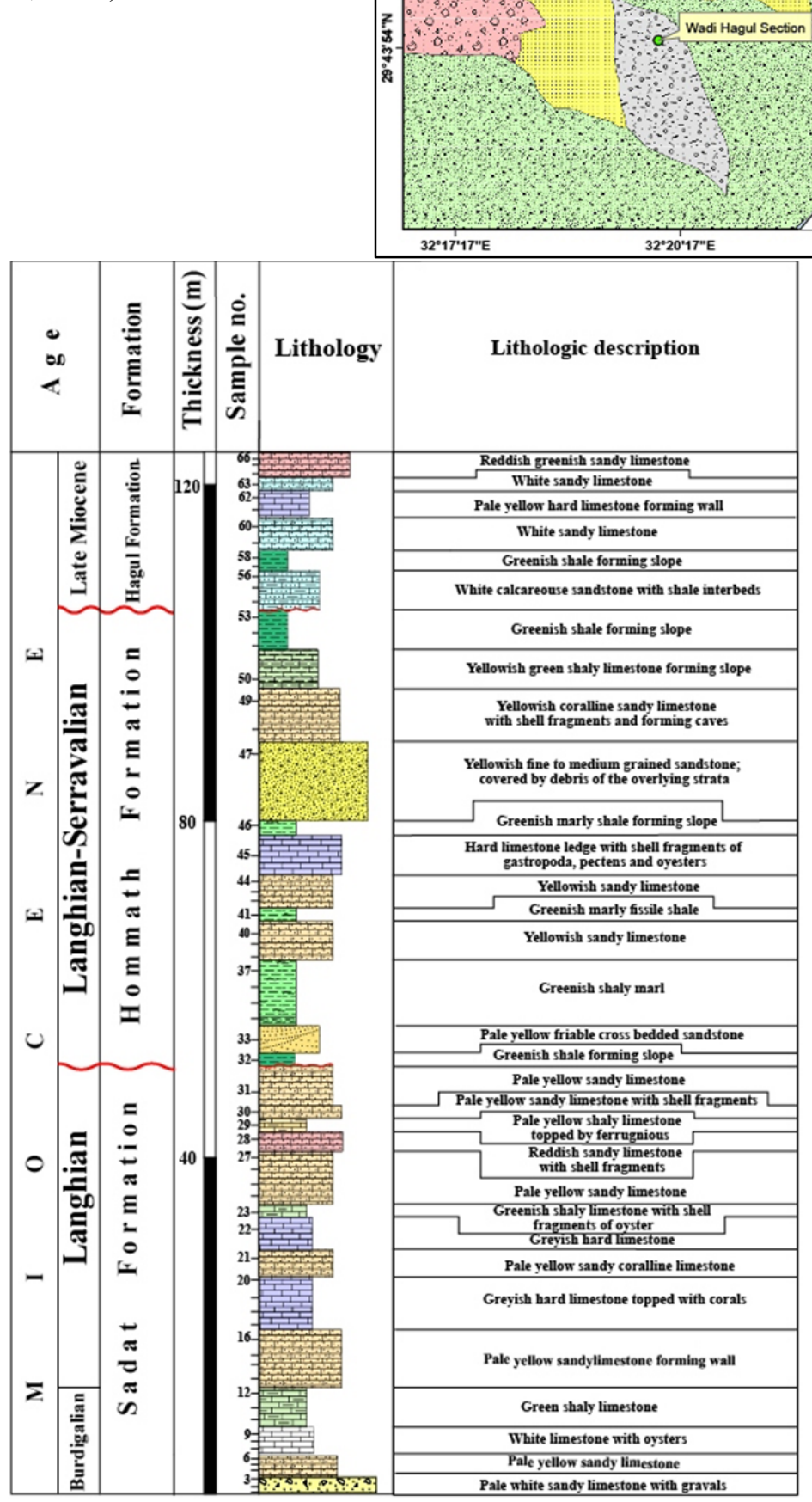

Fig. 2: A composite stratigraphic section exposed in the Sadat area. 
Biostratigraphy of the miocene successions in the Sadat area

\section{Material and Methods}

The present study is based on the examination and investigation of calcareous nannofossils and foraminifera found in 66 rock samples collected from three Miocene sections at Sadat area. These are Wadi Ramiya section (Latitude $29^{\circ} 46^{\prime} 45^{\prime \prime}$ and Longitude $32^{\circ} 24^{\prime}$ ' "'), Wadi Hommath section (Latitude $29^{\circ} 45^{\prime} 25^{\prime \prime}$ and Longitude $32^{\circ} 21^{\prime} 8^{\prime \prime}$ ) and Wadi Hagul section (Latitude $29^{\circ} 44^{\prime}$ and Longitude $32^{\circ} 2^{\prime}$ ) (Fig.1). The samples were prepared for foraminiferal investigations and calcareous nannofossils examination (Figs 3, 4, 5 and 6).

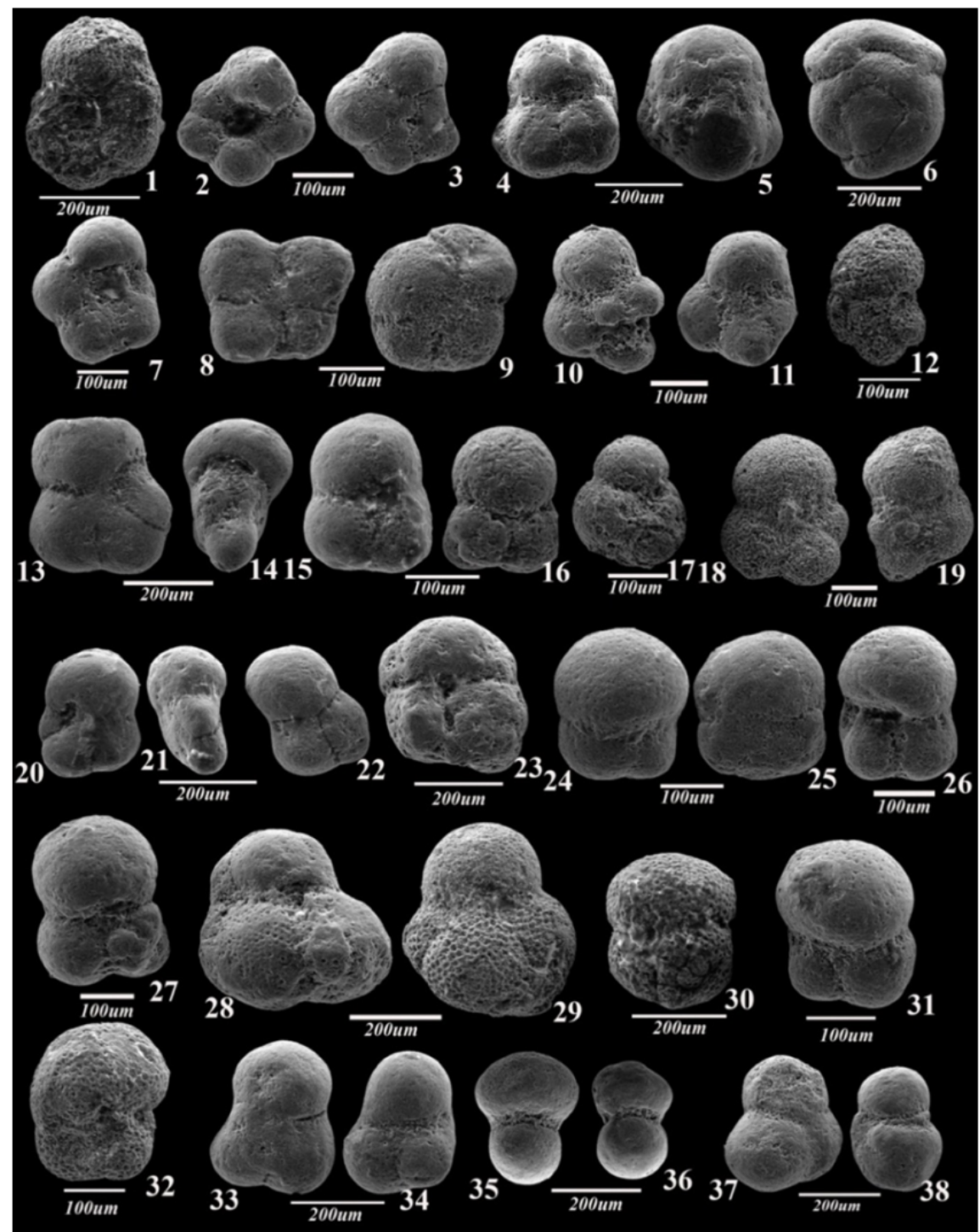

Fig. 3: Paragloborotalia mayeri (Cushman and Ellisor), sample No. 9. 2-3. Turborotalita quinqueloba (Natland), sample No. 15. 4-5. Catapsydrax pravulus (Bolli, Loeblich and Tappan), sample No. 18. 6. Globoquadrina dehiscens (Chapman, Parr and Collins), sample No. 13. 7. Globigerina angustiumbilicata (Bolli), sample No. 18. 89. Globigerina diplostoma (Reuss), sample No. 15. 10-11. Globigerina falconensis (Blow), sample No. 40. 12. Globigerinella obesa (Bolli), sample No. 17. 13-14. Globigerinella praesiphonifera (Blow), sample No.18. 15-16. Globoturborotalita connecta (Jenkins), sample No.17. Globoturborotalita druryi (Akers), sample No. 17. 18-19. Globoturborotalita occulusa (Blow and Banner), sample No. 50. 20-22. Globoturborotalita pseudopraebulloides (Blow), sample No.18. 23. Globigerinoides subquadratus (Brönnimann), sample No. 4. 24-25. Trilobatus bisphericus (Todd and Post), sample No. 50. 26-27. Trilobatus immaturus (Le Roy), sample No. 17. 28-29. Trilobatus quadrilobatus (d'Orbigny), sample No. 21. 30-Trilobatus sacculiferus (Brady), sample No. 23.31. Trilobatus sicanus (De Stefani), sample No. 17. 32-33. Trilobatus trilobus (Russ), sample No. 17. 34-35. Sphaeroidinellopsis disjuncta (Finlay), sample No. 17. 36-37. Orbulina bilobata (d'Orbigny), sample No. $28.38-39$. Praeorbulina transitoria (Blow), sample No. 17. 
Hewaidy, et al.

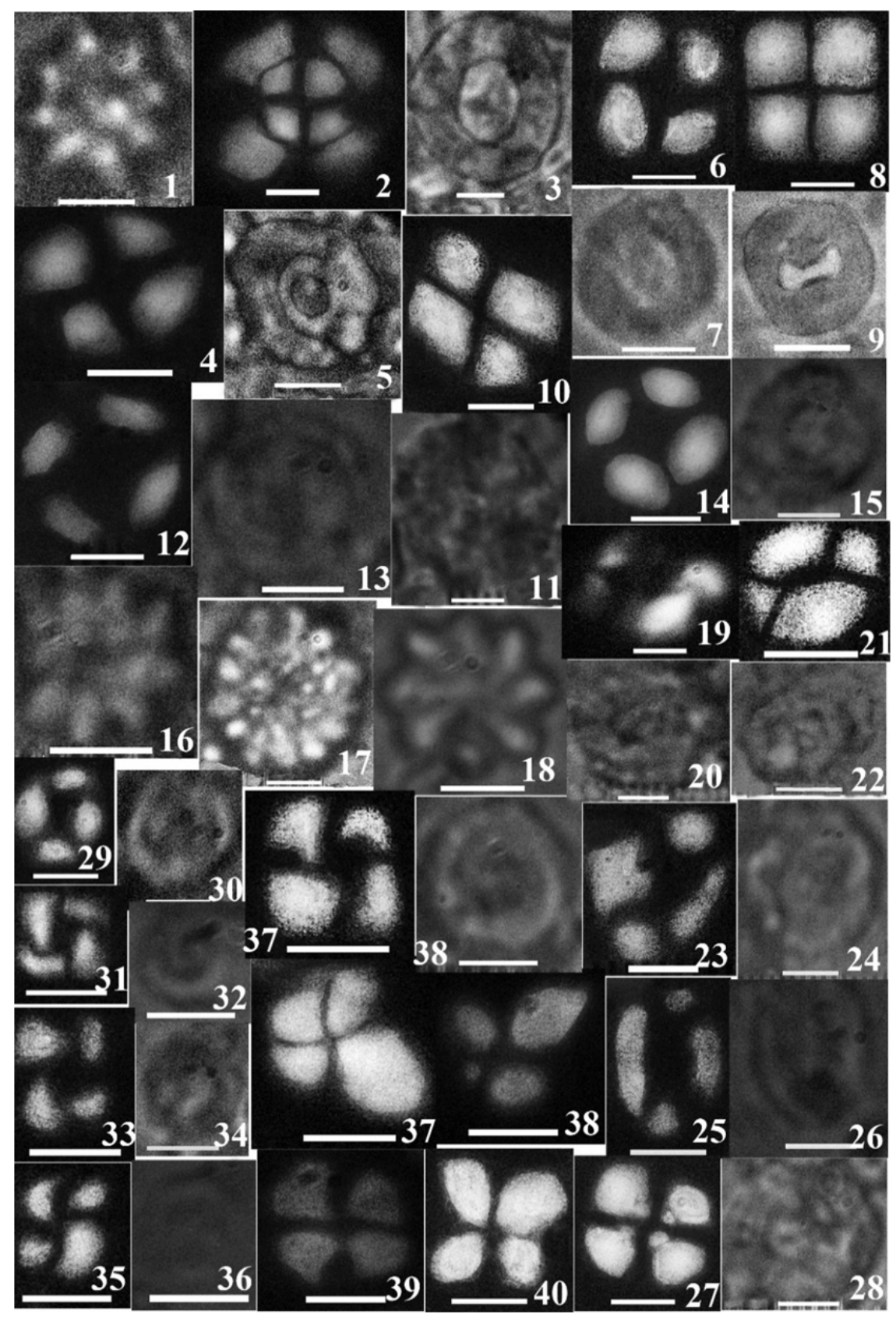

Fig. 4: Corannulus germanicus (Stradner), sample No. 47. 2-3. Coccolithus miopelagicus (Bukry), sample No. 45. 4-5. Coccolithus pelagicus (Wallich), sample No. 45. 6-7. Ericsonia cava (Hay et al), sample No. 47. 8-9. Ericsonia ovalis (Black), sample No. 49 10-11. Calcidiscus leptoporus (Murry and Blackman), sample No. 47. 12-13. Coronocyclus nitescence (Kamptner), sample No. 45. 14-15. Pyrocyclus hermosus (Hay Mohler and Wade), sample No. 45. 16. Discoaster mohleri (Martini), sample No. 47. 17. Discoaster nobilis (Martini), sample No. 45. 18. Hayaster perplexs (Bramlette and Riedel), sample No. 47. 19-20. Helicosphaera ampliaperta (Bramlette and Wilcoxon), sample No. 29. 21-22. Helicosphaera carteri (Wallich), sample No. 47. 23-24. Helicosphaera oblique (Bramlette and Wilcoxon), sample No. 45. 25-26. Pontosphaera discopora, sample No. 47. 27-28. Cyclicargolithus floridanus (Hay et al.), sample No. 49. 29-30. Reticulofenestra haqii (Backman), sample No. 49. 31-32. Reticulofenestra minuta (Roth), sample No. 49. 33-34. Reticulofenestra producta (Kamptner), sample No. 47. 35-36. Reticulofenestra pseudoumbilica, (Gartner), sample No. 49. 37-38. Sphenolithus heteromorphus (Deflandre), sample no. 47. 39-40. Sphenolithus moriformis, (Bronnimann and Stradner), sample No. 45. 
Biostratigraphy of the miocene successions in the Sadat area
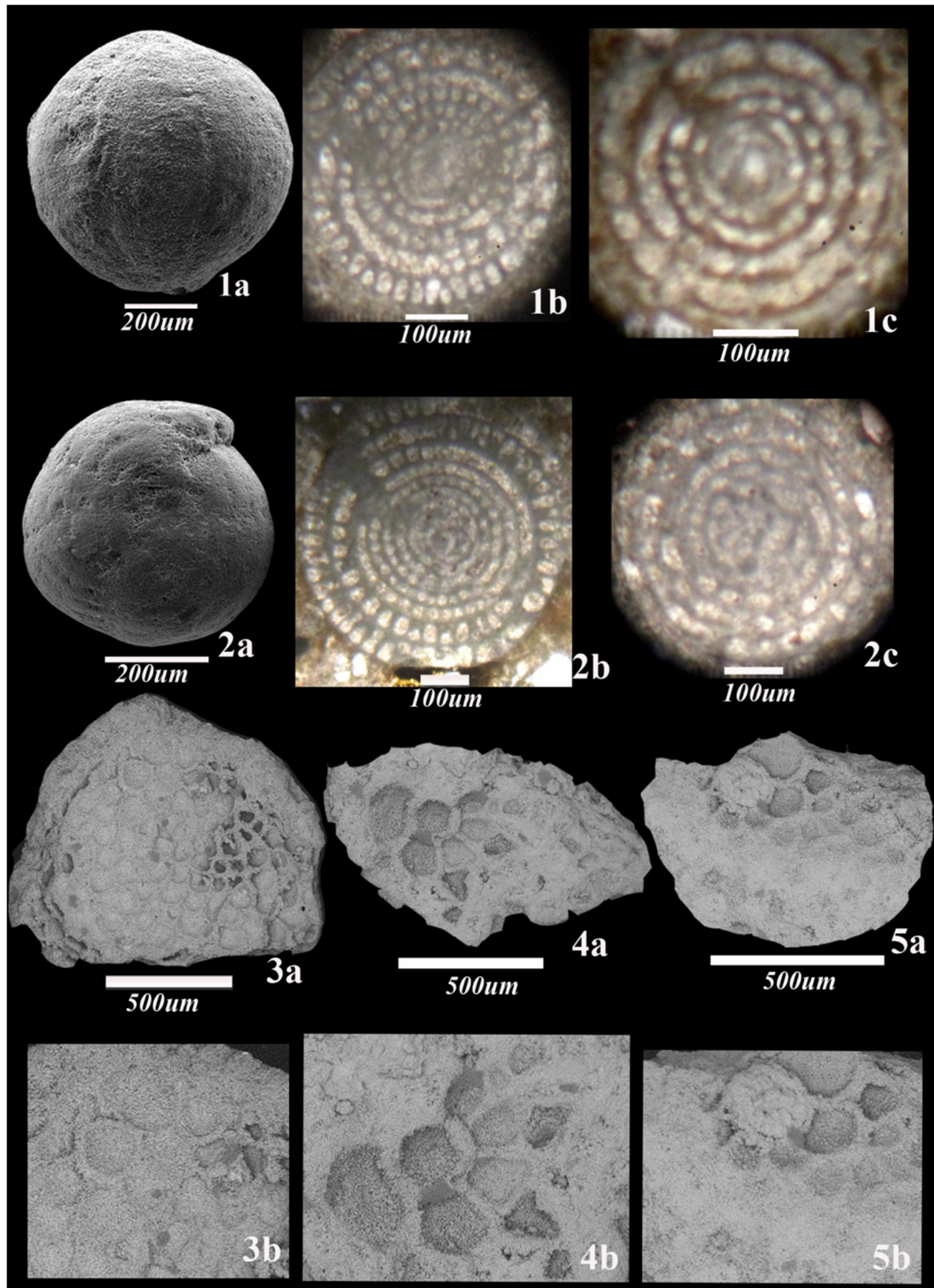

Fig. 5. 1. Borelis melo curdica (Reichel), sample no. 50, 1a. external view, 1b. axial view, 1c. equatorial view. 2. Borelis melo melo (Fichtel and Moll), sample no. 50, 2a. external view, 2b. axial view, 2c. equatorial view. 3. Miogypsina cushmani (Vaughan), sample no. 4. Figs. 4-5. Miogypsina intermedia (Drooger) sample no. 4, 6. 
Hewaidy, et al.

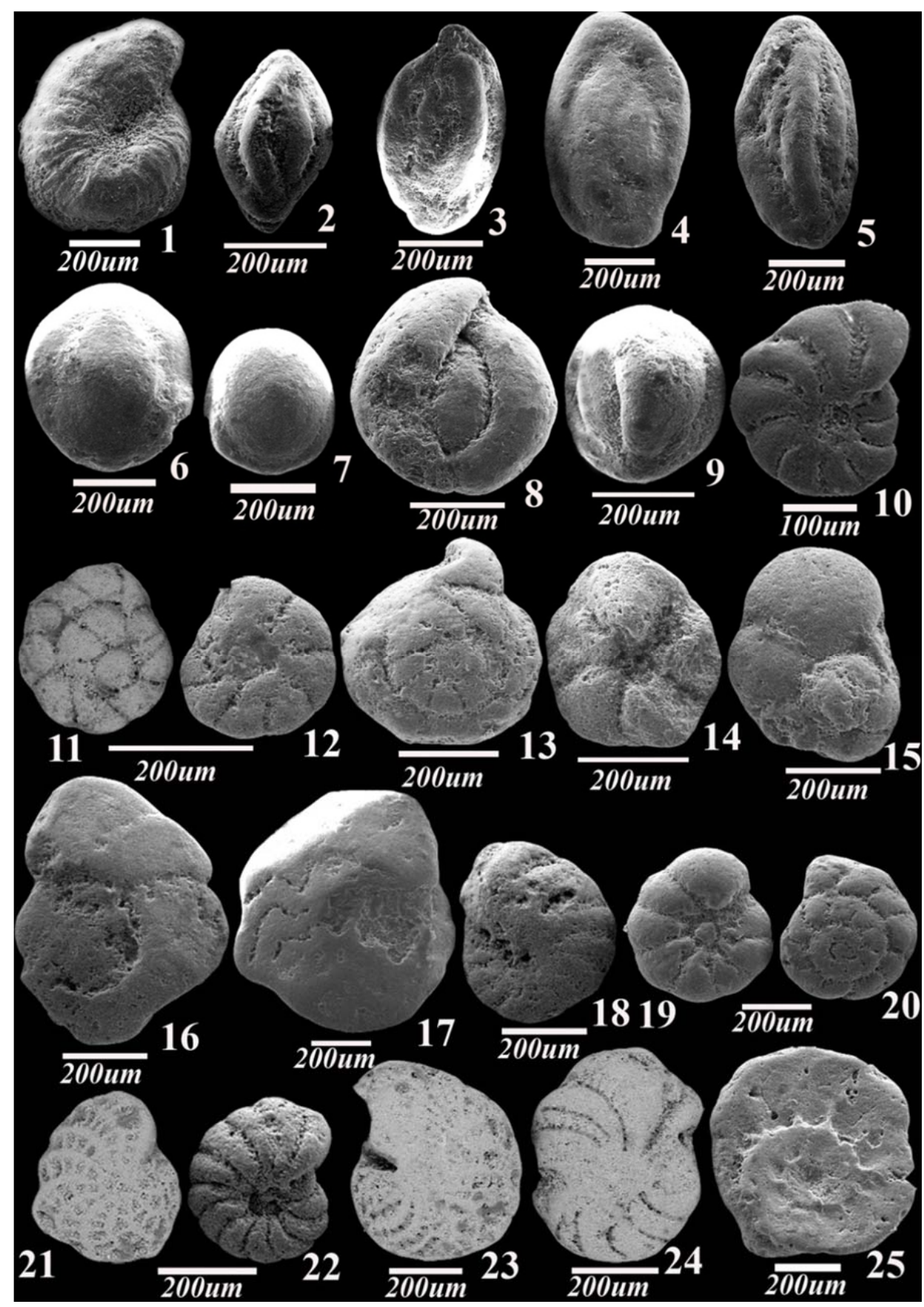

Fig. 6: 1. Veleroninoides scitulus (Brady), sample No. 49, 2. Quinqueloculina akneriana (d' Orbigny), sample No. 3. Quinqueloculina berthelotiana (d' Orbigny), sample No. 21, 4-5. Quinqueloculina laevigate (d' Orbigny) sample No. 24, 6. Pyrgo anomala (Schlumberger) sample No., 7. Pyrgo depressa (d' Orbigny) sample No. 15, 8. Triloculina rotunda (d' Orbigny) sample No. 50, 9. Triloculina trigonula (Lamarck) sample No. 38, 10. Peneroplis proteus (Forskal) sample No. 49, 11-12. Valvulineria complanata (d' Orbigny) sample No. 4, 13. Discorbis dimidiatus (Parker and Jones), sample No. 39, 14. Gavelinopsis holkos (Finger and Lipps), sample No. 30, 15. Rosalina obtusus (d' Orbigny) sample No. 39, 16. Cibicidella variabilis (d' Orbigny) sample No. 10, 17. Amphistegina lessonii (d' Orbigny) sample No. 14, 18. Nonion boueanus (d' Orbigny) sample No. 15, 19-20. Ammonia beccarii (Linné) sample No. 50, 21. Elphidium advenum (Cushman) sample No. 4, 22. Elphidium antoninum (d' Orbigny) sample No. 39, 23. Elphidium crispum (Linne') sample No. 39, 24. Elphidium macellum (Fichtel and Moll), sample No. 13, 25. Operculina carpanteri (Silvesteri) sample No. 13. 
Biostratigraphy of the miocene successions in the Sadat area

\section{Biostratigraphy}

The foraminiferal and nannofossil contents are restricted to certain horizons in the three studied sections. A detailed investigation of the studied samples revealed two larger benthic foraminifera contributed in age determination (Fig. 5). Otherwise the planktonic foraminifera and calcareous nannofossils assemblages are not significant in age determinations (Figs. 8, 9, 10, 11 and 12).

\section{Foraminiferal biozones}

\section{Biozone (SB 25) Miogypsina zone}

Definition: In the present study, the lower boundary of this zone is defined by the presence of Miogypsina cushmani and M. intermedia, while its upper boundary is delimited by the extinction of these species (Ogg et al., 2016).

Author: Cahuzac and Poignant (1997).

Age: Early Miocene (Late Burdigalian).

Stratigraphic position: It is recorded in the lower part of the Sadat Formation at Wadi El-Ramiya section (Fig. 8).

Remarks and correlation: Miogypsina is the most conspicuous large benthic foraminiferal taxon recorded in this zone. Drooger (1952 and 1993) assigned the Miogypsina group which includes (Miogypsina intermedia, M. cushmani, M. globulina and M. complanata) to the Burdigalian Age. In Egypt, Souaya (1961and1963) and Cherif (1966) recorded Miogypsina intermedia from the Miocene deposits of Cairo-Suez district and assigned the rocks to the Burdigalian. Nassif et al., (1992) recorded the same species from the Miocene sequence of Wadi Feiran, south west Sinai and assigned the assemblage to the early Miocene (Burdigalian). Ouda (1998) described Miogypsina intermedia and M. cushmani from the Miocene deposits of the northern Western Desert and assigned to late Burdigalian. Abdelghany and Piller (1999) recorded the Miogypsina intermedia and M. cushmani from the early Miocene Gharra and Sadat formations in Cairo-Suez district and assigned to late Burdigalian age. Imam and Refaat (2000) identified these species from the early Miocene deposits of Wadi Abura and Gabal Hammam Sayidna Musa, southern Sinai. Abdelghany (2002) recorded the Miogypsina intermedia from Gebel Shabrawet area north Eastern Desert and assigned to Burdigalian age. Hamad (2009) recorded Miogypsina cushmani and M. intermedia from the lower part of the Sadat Formation, Sadat area, Cairo-Suze district and assigned them to early Miocene (early Burdigalian). Moreover, the presence of the larger benthic foraminifera Miogypsina intermedia that is widely distributed throughout the Tethys Ocean and known to be restricted to the late early Miocene (Burdigalian); Wildenborg, 1991; Drooger, 1993; Cahuzac and Poignant, 1997; Özcan et al., 2009. Furthermore, Hamad (2013) recorded Miogypsina intermedia from the Miocene sequence of Wadi Zaqlum, Sirte basin in Libya and assigned to Burdigalian age. Recently geologic time scale workers correspond the first occurrence of Miogypsina cushmani to the base of Zone M4 and corresponds the last occurrence of Miogypsina to the top of M4 zone or (SBZ-25). In the present study, the lower part of the Sadat Formation that assigned to this zone is of the late Burdigalian age according to the presence of Miogypsina intermedia and M. cushmani (Figs. 5 and 8).

\section{Biozone (SB26) Borelis melo zone:}

Definition: this zone is defined by the first occurrence of Borelis melo (Fichtel and Moll) and the disappearance of Miogypsina spp., Ogg et al. (2016).

Author: Cahuzac and Poignant (1997).

Age: Middle Miocene age.

Stratigraphic position: Two distinct spherical subspecies of Borelis melo are recognized including Borelis melo melo (Fichtel and Moll) recorded from the upper part of the Sadat Formation and covering the whole Hommath Formation (Figs. 8 and 9). The second one is Borelis melo curdica (Reichel) recorded only from the upper part of the Hommath Formation (Fig. 9). 
Hewaidy, et al.

Remarks and Correlation: Many workers have discussed the stratigraphical importance of Borelis melo as a zonal marker defining the beginning of the Middle Miocene age. In Egypt, many authors have used the Borelis melo as an evidence for beginning the Middle Miocene age. Souaya (1963a) recorded the Borelis melo with the Miogypsina in the middle Miocene of Gabal Gharra, Cairo-Suez district. Souaya (1963b) recognized the Borelis melo from the middle Miocene- Pliocene in the Red sea. Youssef et al. (1971) recorded the Borelis melo from the upper part of the Sadat Formation in the Sadat area and attributed it to Langhian age (Fig. 7). Szczechura and Abd-Elshafy (1988) recorded the Borelis melo from the Hommath Formation in Bir El-bada area at the western side of the Gulf of Suez and assigned to Middle Miocene age. Imam et al. (1997) recorded this taxon from the Middle Miocene deposits of Sarbut El-Gamal Formation, west central Sinai. Ouda (1998) recorded the Borelis melo from the Miocene successions in the north Western Desert. He considered the Borelis melo as a diagnostic taxon for the late Langhian-Serravallian age. Imam and Refaat (2002) recognized the Borelis melo Zone from the middle Miocene Marmarica Formation in the Sallum area, Western Desert. Abul Naser et al. (2009) recorded this taxon from the Middle Miocene Hammam Faroun Member of Belayium Formation, between Wadi Sudr and Wadi Wardan, Gulf of Suez region. In the present study, two distinct subspecies of Borelis melo are recognized Borelis melo melo (Fichtel and Moll) and Borelis melo curdica (Reichel). The presence of these two species suggests that the upper part of the Sadat Formation and the whole Hommath Formation is of Langhian-Serravallian age.

Fig. 7: Different rock units proposed by different author for the Miocene rocks in the CairoSuez district.

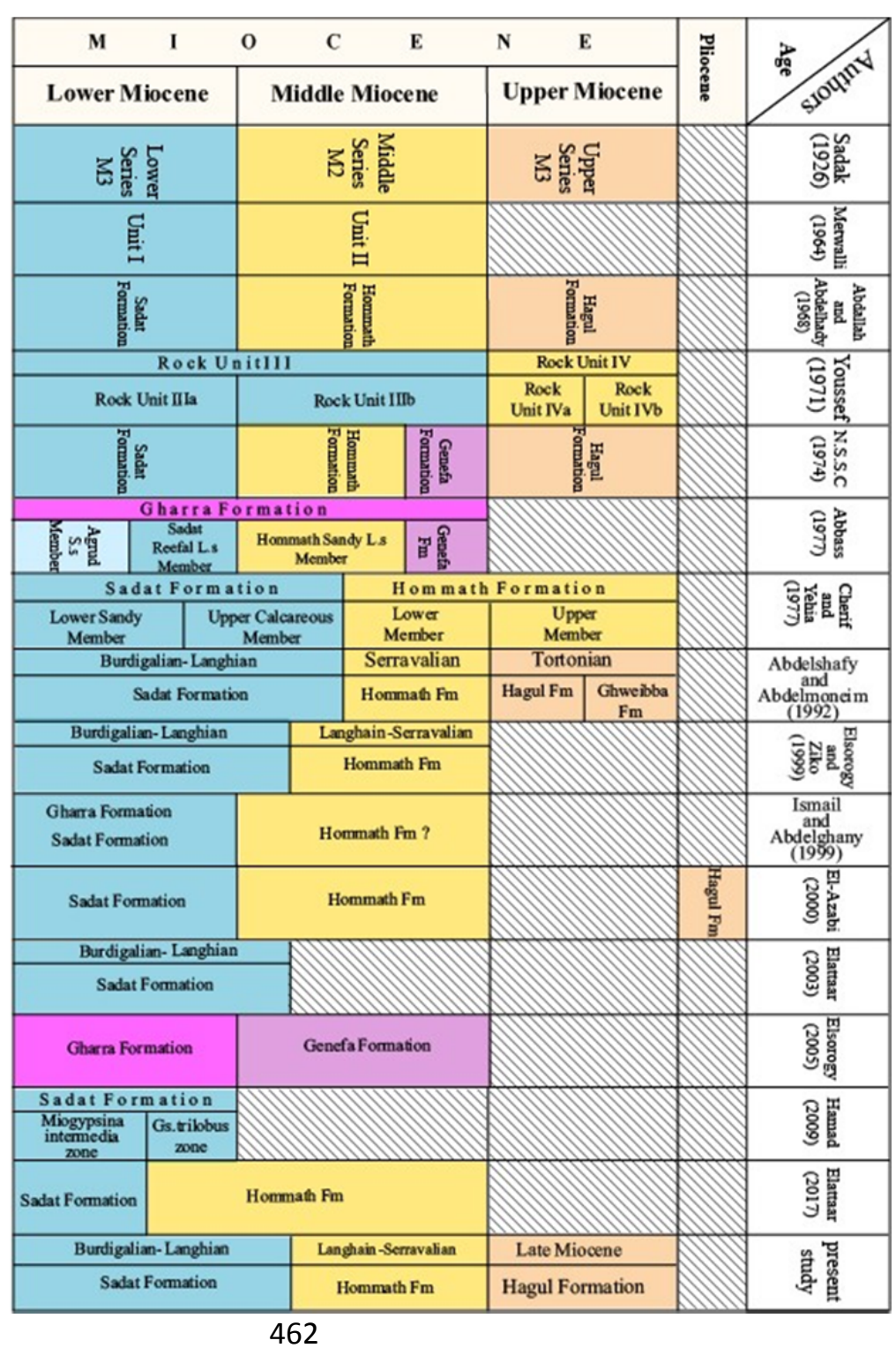


Biostratigraphy of the miocene successions in the Sadat area

\section{Planktic foraminifera}

The planktic foraminiferal assemblage obtained from the studied area is very restricted. It includes 23 species recorded from the Sadat Formation where 14 of them recorded from the Hommath Formation (Figs. 3, 11 and 12). This assemblage is not significant in age determination due to the absence of the age diagnostic taxa (Fig. 3).

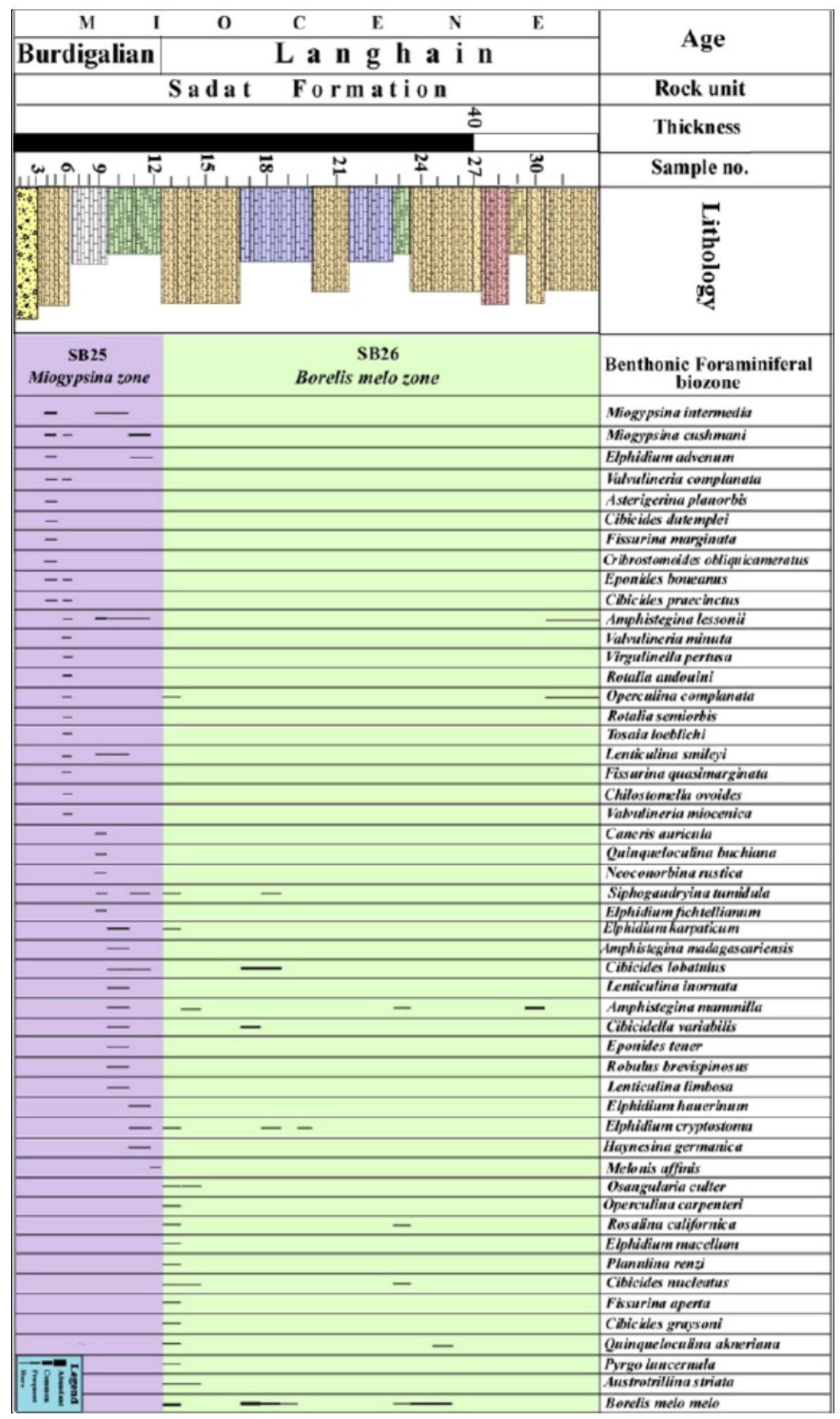

Fig. 8: Distribution chart of the identified benthic foraminiferal species at Wadi El-Ramiya section. 
Hewaidy, et al.

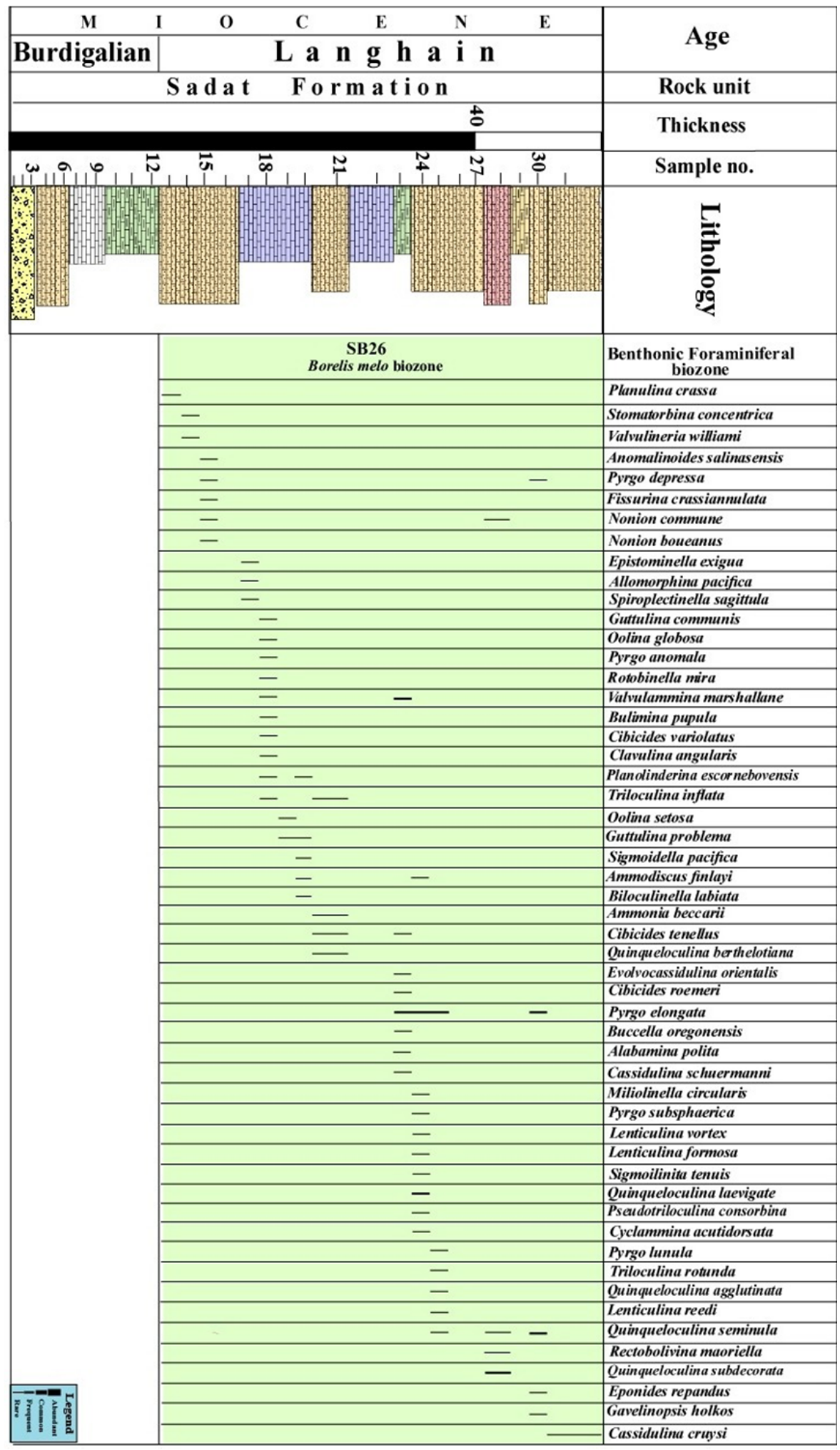

\section{Calcareous nannofossils}

The recognized calcareous nannofossil assemblage described here includes 23 species recorded from the upper part of the Hommath Formation at Wadi Hommath section (sample 45, 47, 49) (Figs. 4 and 12), 
Biostratigraphy of the miocene successions in the Sadat area

six of them are recorded from the Sadat Formation (sample 4, 8, 26, 29) (Figs. 4 and 11). This nannofossil assemblage is poorly represented in the studied samples and sometimes only by single individual. Most of these species are not significant for age determination (Fig. 4). Only Helicosphaera ampliaperta that recorded from the upper part of the Sadat Formation and the lower part of the Hommath Formation that may refers to Helicosphaera ampliaperta Zone of early-middle Miocene Age. (Fig. 12).

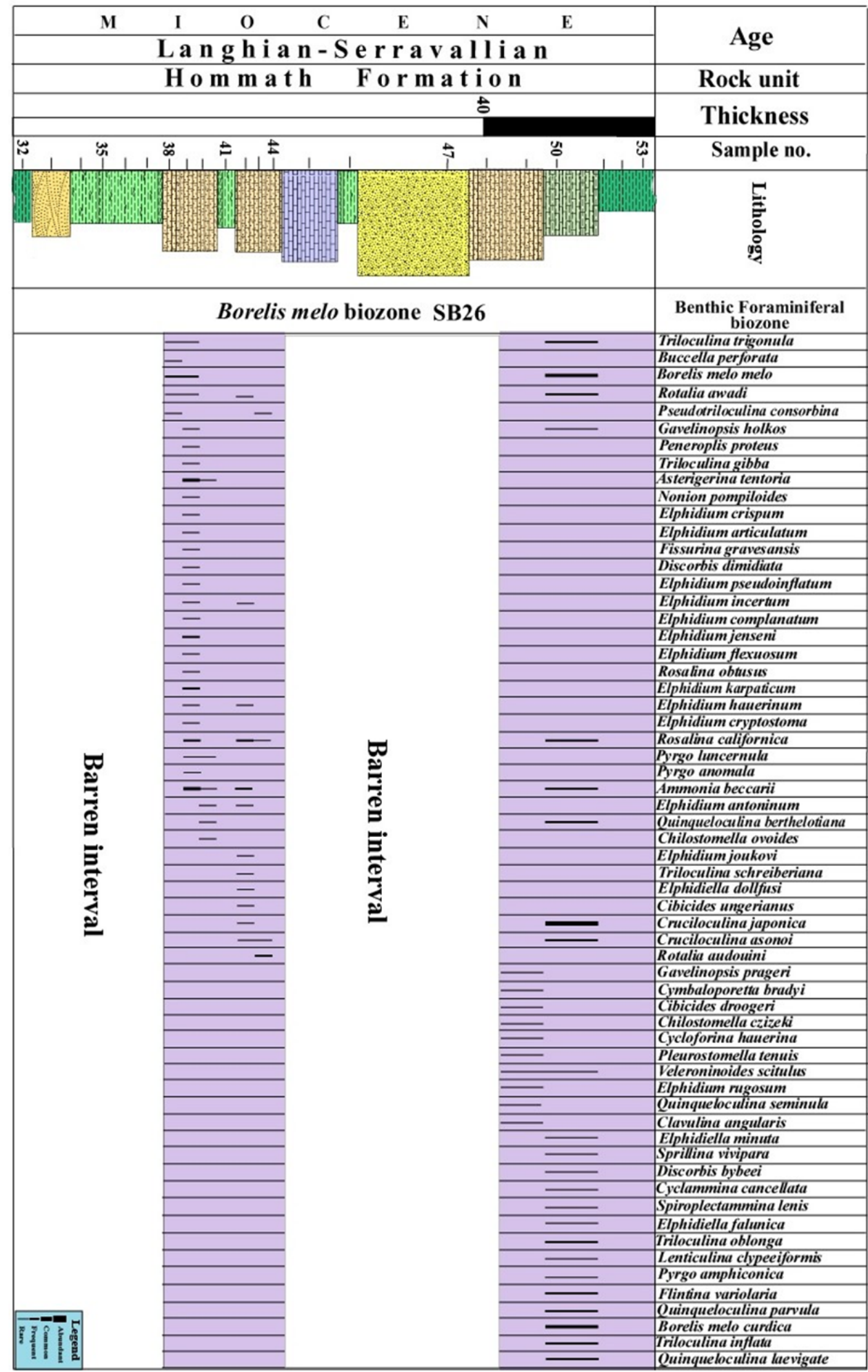

Fig. 9: Distribution chart of the identified benthic foraminiferal species at Wadi Hommath section. 
Hewaidy, et al.

Fig. 10: Distribution chart of the identified benthic foraminiferal species at Wadi Hagul section.

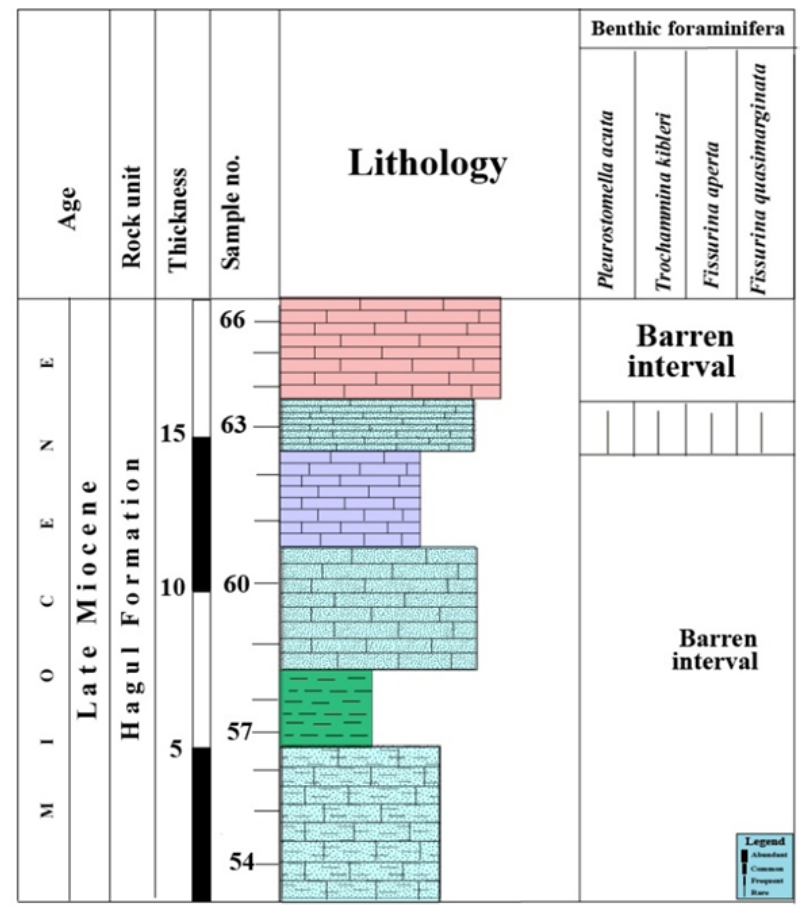

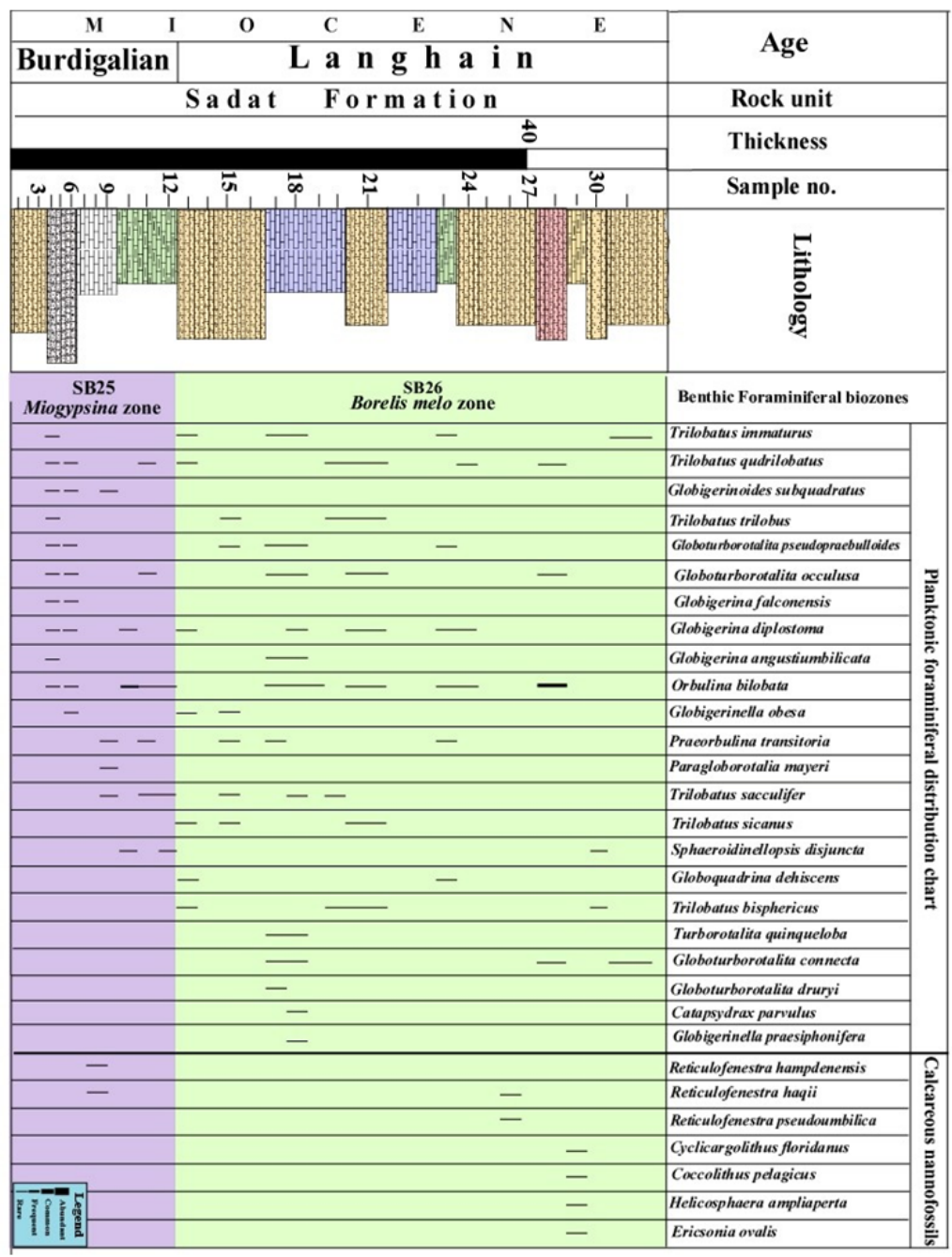

Fig. 11:

Distribution chart of the identified planktic Foraminiferal and calcareous nannofossil species at Wadi El-Ramiya section. 
Biostratigraphy of the miocene successions in the Sadat area

Fig. 12: Distribution chart of the identified planktic Foraminiferal and calcareous nannofossil species at Wadi Hommath section.

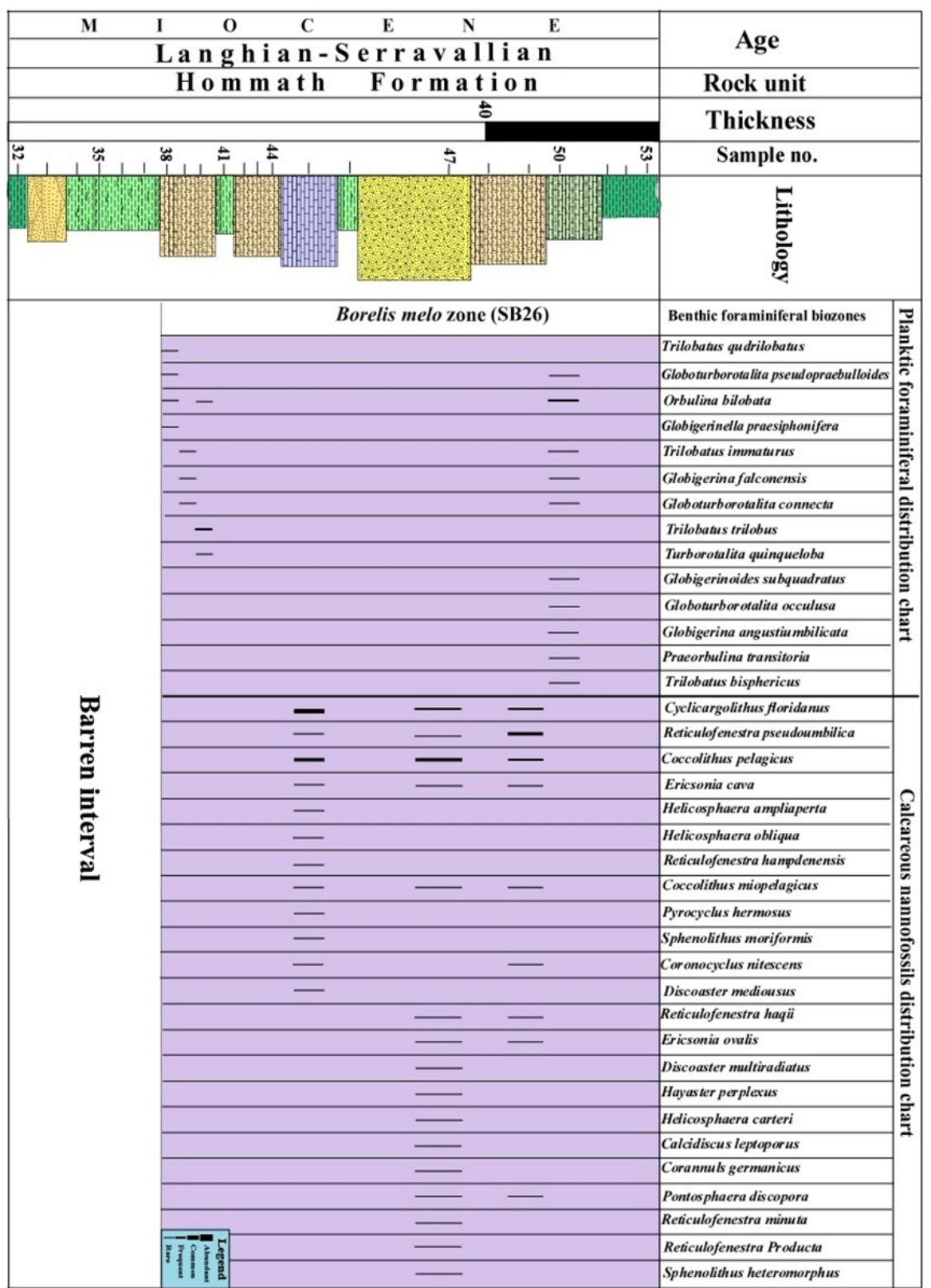

\section{CONCLUSIONS}

Three Miocene sections were measured from Sadat area on the west side of the Gulf of Suez, Egypt. These sections are subdivided from older to younger into Sadat Formation (Burdigalian- Langhian), Hommath Formation (Langhian-Serravallian), and Hagul Formation (late Miocene). The detailed investigations of the biostratigraphic data obtained from the studied sections led to the identification of 23 calcareous nannofossil species, 23 planktic foraminiferal species and 152 benthic foraminiferal species (Figs. 6, 8 and 10). The identified planktic foraminifera and calcareous nannofossil are not sufficient for establishing the biostratigraphic zonation. The stratigraphic distribution of larger benthic foraminifera allowed the subdivision of the Miocene sequences into two larger benthic foraminiferal biozones arranged from older to younger: Miogypsina zone (SP25) of Burdigalian Age and Borelis melo zone (SP26) of Langhian-Serravallian ages. The Sadat Formation occupied by two biozones Miogypsina intermedia, M. cushmani Zone in the lower part and Borelis melo Zone in the upper part while the Hommath Formation is assigned to Borelis melo Zone. The Hagul Formation is barren from the age diagnostic taxa and assigned to the late Miocene age according to its stratigraphic position (Fig. 10). 
Hewaidy, et al.

\section{REFERENCES}

Abbass H. L. (1977) A monograph on the new Miocene gastropod species in the Cairo-Suez district, Egypt. J. Univ. Kuwait (Sci) 4:83-158.

Abdallah, A. M. and Abdel Hady, F. M. (1968): Geology of Sadat area, Gulf of Suez - J. Geol. U.A.R, 10/1 (1966): 1-22.

Abdelghany, O. and Piller, W. E. (1999): Biostratigraphy of Lower Miocene sections in the Eastern Desert (Cairo-Suez district, Egypt).- Rev Paléobiol, Geneve 18/2, 607-617.

Abdelghany, O. (2002): Lower Miocene stratigraphy of the Gebel Shabrawet area, North Eastern Desert, Egypt. J. Afr. Earth Sci, 34, 203-212.

Abdelshafy E, Abdel-Elmoneim M. (1992): Lithostratigraphy of the Miocene rocks in the area between Gabal Ataqa and the northern Galala, Eastern Desert, Egypt. Bull. Fac. Sci., Zagazig Univ., 14(12), 290-302.

Abul-Naser, R., Y. El safori, S. Attia, and A. Maih, (2009): Stratigraphy and depositional settings of the Miocene succession in the area between Wadi Suder and Wadi Wardan, Gulf of Suez region . Egypt. J. Paleontol. 9: 121-147.

Ayyad, H. M., El-Sharnoby, A. A., El-Morsy, A.M., Mustafa, A. A. and El-Deeb, A. A (2018): Quantitative reconstruction of paleoenvironmental conditions in the Gulf of Suez during the Burdigalian-Langhain (early-middle Miocene) using benthic foraminifera. Palaeogeogr, Palaeoclimatol, Palaecol. 51-68.

Cahuzac, B. and Poignant, A. (1997): Essai de biozonation de I'Oligo-Miocene dans les bassins européens á l'aide des grands foraminiféres néritiques. - Bull. Soc. Géol. Fr., 168/2: 155-169.

Cherif O. H. (1966): The Geology of the Sadat area, Southwest of Suez, Egypt. M. Sc. Thesis, Fac. Sci., Ain Shams Univ., Cairo, Egypt. 242p.

Cherif O. H. and Yehia M. A. (1977): Stratigraphy of the area between Wadi Gimal and Wadi Hommath, Gulf of Suez, Egypt. Egypt. J. Geol., 21(2): 185-203.

Conoco, Coral, 1987. Geological map of Egypt, scale 1:500,0000-NF 36-Bernice, Egypt. E.G.P.C, Egypt.

Drooger, C. W. (1952): Study of American Miogypsinidae. Ph. D. Thesis, University of Utrecht, Vonk and Co., Zeist, p. 80.

Drooger, C.W. (1993): Miogypsinidae. In: Drooger, C.W., (Ed.), Radial Foraminifera: Morphmetrics and Evolution. Verhandelin-gen der Koninklijke Nederlandse Akademie van Wetenschappen, Afd Natuurkunde, North Holland 41, VIII, 74-112.

Elattaar, A. A. A. (2003): Early-middle Miocene echinoides from the Sadat Formation, Sadat area, south Gebel Ataqa, NW Gulf of Suez, Egypt. Egypt. J. Paleont. 3: 209-241.

Elattaar, A. A. A. (2017): Miocene echinoides from the Sadat area, south Gebel Ataqa, NW Gulf of Suez, Egypt: systematics, palaeobiogeography. Arab J. Geosci. 10/250, 1-29.

El-Azabi M. H. (2000): Sedimentary facies, paleoenvironments and facies development of MiocenePliocene sequences in the Sadat-Wadi Hagul stretch, northwest Gulf of Suez and their time correlatives in the adjacent basins, Egypt. $5^{\text {th }}$ Int. Conf. Geol.of the Arab World, Cairo Univ., Egypt. 1135-1174.

El-Sorogy, A. S. and Ziko, A. (1999): Facies development and environments of Miocene reefal limestone, Wadi Hagul, Cairo-Suez District, Egypt. - N. Jb. Geol. Palaönt. Mh., 1999/4: 213-226.

Gargani, J., Moretti, I., Letouzey, J., 2008. Evaporite accumulation during the Messinian salinity crisis: the Suez Rift case. Geophys. Res. Lett. 35 (2), L02401.

Hamad M. M. (2009): Coralline red algae and Foraminiferal biostratigraphy of the early Miocene Sadat Formation, Sadat area, northwest Gulf of Suez, Egypt. Egypt. J. Paleontol 9, 183-212.

Hamad M. M. (2013): Biostratigraphy and Paleoecology of the Miocene sequence along the stretch of Qabilt ash Shurfah to Wadi Zaqlum sections, Sirte Basin, Libya. Aust. J. Basic and Appl. Sci., 7(10): 513-531.

Ismail A. A. and Abdelghany O. (1999) Lower Miocene foraminifera from some exposures in the CairoSuez district, Eastern Desert, Egypt. J. Afr. Earth Sci., 28(3), 507-526.

Imam, M. M. (1997): Planktonic foraminiferal biostratigraphy of the Miocene sequence in the area between Wadi El Tayiba and Wadi Sidri, west central Sinai, Egypt. N. Jb. Geol. Palaont. Abh. 7: 409439. 


\section{Biostratigraphy of the miocene successions in the Sadat area}

Imam, M. M. and Refaat. (2000): Stratigraphy and Microfacies analysis of the Miocene sequence in the area between Gabal Hammam Sayidna Musa and Wadi Abura, south Sinai, Egypt. N. jb. Geol. Palaont. Abh. 7: 385-409.

Imam, M. M. and Refaat. (2002): Biostratigraphy paleoecology of the early Pliocene sequence, Salum area, North Western Desert, Egypt. Rev. Esp. Micropaleontol, 34(1), 19-38.

Issawi, B., M. Elttinnawi, M. Francis and A.Mazhar, (1999): The Phanerozoic geology of Egypt, a geodynamic approach. Egypt, Geol. Surv., Spec. Publ. 76.

Metwalli, M. M. (1964): The study of some Miocene sediments in Cairo-Suez district. M. Sc. thesis, Fac. Sci., Cairo Univ.

Nassif, M. S., Aboul El-Enein, M. K., El-Heiny, I. A. and El-Ghawaby, M. A. (1992): Stratigraphy of the Miocene rocks at Wadi Feiran, southwest Sinai, Egypt. Proc. ${ }^{\text {rd }}$ Conf. Geol. Sinai Develop., Isamalia, 161-174.

N.S.S.C. (1974): Rock stratigraphy of Miocene in the Gulf of Suez region. - Egypt J, Geol., 18, No. 1.

Ogg, J., Ogg, G., and Gradstein, F. (2016). A concis geologic timescale, Amsterdam: Elsevier, 299 pp.

Ouda, K. (1998): Biostratigraphy, paleoecology paleogeography of the middle late Tertiary deposits of the northern Western Desert, Egypt. - N. Jb. Geol. Paläont. Abh., 207/3, 311-394.

Özcan, E., Less, G., Bàldi-Beke, M., Kollànyi, K. and Acar, E. (2009): Oligo-Miocene foraminiferal record (Miogypsinidae, Lepidocyclinidae and Nummulitidae) from the Western Taurides (SW Turkey): Biometry and implications for the regional geology. J. Asian Earth Sci. 34, 740-760.

Popov, S. V., Rögl, F., Rozanov, A. Y., Steininger, F. F., Shcherba, I. G. and Kovàč, M., (2004): Lithological-paleogeographic maps of paratethys. Cour. Forschungsinst. Senck. 250, 1-46.

Sadak H. (1926): the geography and geology of the district between Gebel Ataqa and El-Galala ElBahariya (Gulf of Suez). - Geol. Surv. Min. Res. Dept. Cairo, 120 p.

Sadak H. (1959): The Miocene in the Gulf of Suez region (Egypt). Geol. Surv. Egypt, 1- 18.

Souaya, F.J. (1961): Contribution to the study of Miogypsina s.l. from Egypt. Proc. Kon. Nederl. Akad. Wetenshap., Ser., B, 64 (5): 665-705.

Souaya, F. J. (1963a): On the foraminifera of Gebel Gharra (Cairo-Suez road) and other Miocene samples. J Paleontol, 37 (2), 433-457.

Souaya, F. J. (1963b): Micropaleontology of four sections south of Qusier, Egypt. Micropaleontol, 9 (3): 233-266.

Strougo, A. Faris, M. Tammam, M. and Abul-Nasr, R. (2006): Miocene microfossils from the typelocality of the Hommath Formation (Sadat area, Suez-Ain Sukhna road) and their biostratigraphic implications. M.E.R.C., Ain Shams Univ, Earth Sci. 20, 77-96.

Szczechura, J. and Abd-Elshafy, E., (1998): Ostracods and foraminifera from the Middle Miocene of the western coast of the Gulf of Suez, Egypt. Acta Palaeont. Polonica, 33(4): 273-342.

Youssef, M. I., Bassiouni M. A. and Cherif O. H. (1971) some stratigraphic and tectonic aspects of the Miocene in the northeastern part of the Eastern Desert (Egypt). Bull. Ins. Egypt. 52: 119-155.

Youssef, M. I., Bassiouni M. A., Cherif O. H. (1973): Microfacies of the Tertiary rocks of the Sadat area (southwest of Suez). Bull. Ins. Egypt. 53/54: 79-90.

Wildenborg, A. F. B. (1991): Evolutionary aspects of the miogypsinids in the Oligo-Miocene carbonates near Mineo (Sicily). Utrecht. Micropale. Bull., 41, 1-139. 
Hewaidy, et al.

\section{بيواستراتجرافية تتابعات الميوسين بمنطقة السادات، غرب خليج السويس - مصر. \\ عبدالجليل عبدالحميد هويدي و هيثم محمد عياد و ناصر أحمد محمود \\ قسم الجيولوجيا - كلية العلوم - جامعة الأزهر بالقاهرة.}

\section{الخلاصة}

يتضمن هذا البحث الدراسة البيوستراتجرافيا لمنطقة السادات الواقعة في جنوب جبل عتاقة على الجانب الغربي لخليج

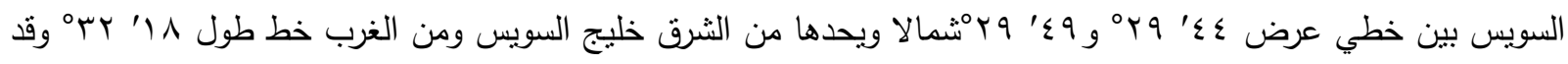

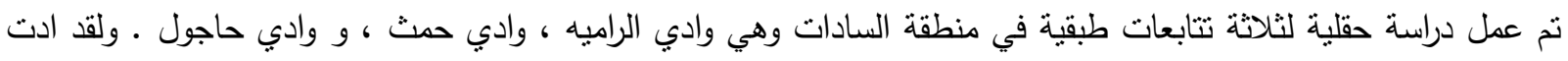
هذه الدراسة الى التعرف على ثنلاث وحدات صخرية ترتيبها من الاقدم الى الاحدث كالتالي: مكون السادات (يتميز بوجود

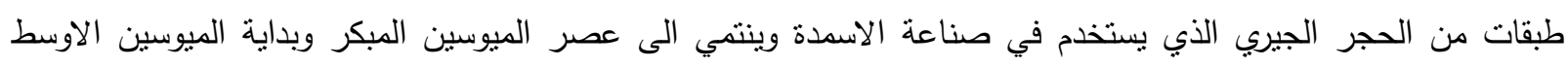
بالمنطقة)، مكون حمث (يتكون من طبقات منبادلة من الصخر الرملي والطفلي وينتمي الى عصر الميوسين الأوسط) ، مكون

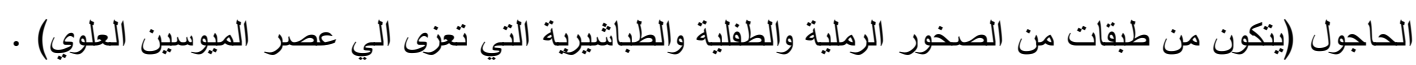
وقد ادت دراسة الوضع التصنيفي لكلا من الفورامينفرا والنانو بلانكتون الي تعريف 152 نوعا من الفورامنيفرا القاعية و 23

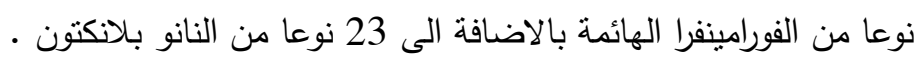

لعبت الفورامينيفرا القاعية الكبيرة دورا اساسيا في تحديد النطاقات الحيوية لهذه التتابعات في ظل غياب الحفريات ذات الدلالة الزمنية الواضحة من الفورامينيفرا الهائمة و النانو بلانكتون. من هذه الدراسة تم تعريف نطاقين من الفورامينيفرا الكبيرة

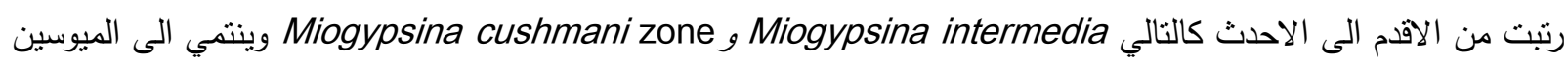
المبكر ويغطي الجزء السفلي لمكون السادات و Borelis melo zone ، وينتمي هذا النطاق الى الميوسين الاوسط ويشغل

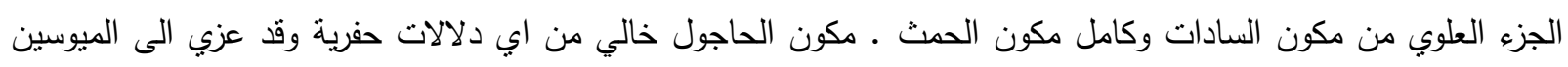
العلوي بناءا علي وضعه الاستراتجرفي من مكون الجنادوات 